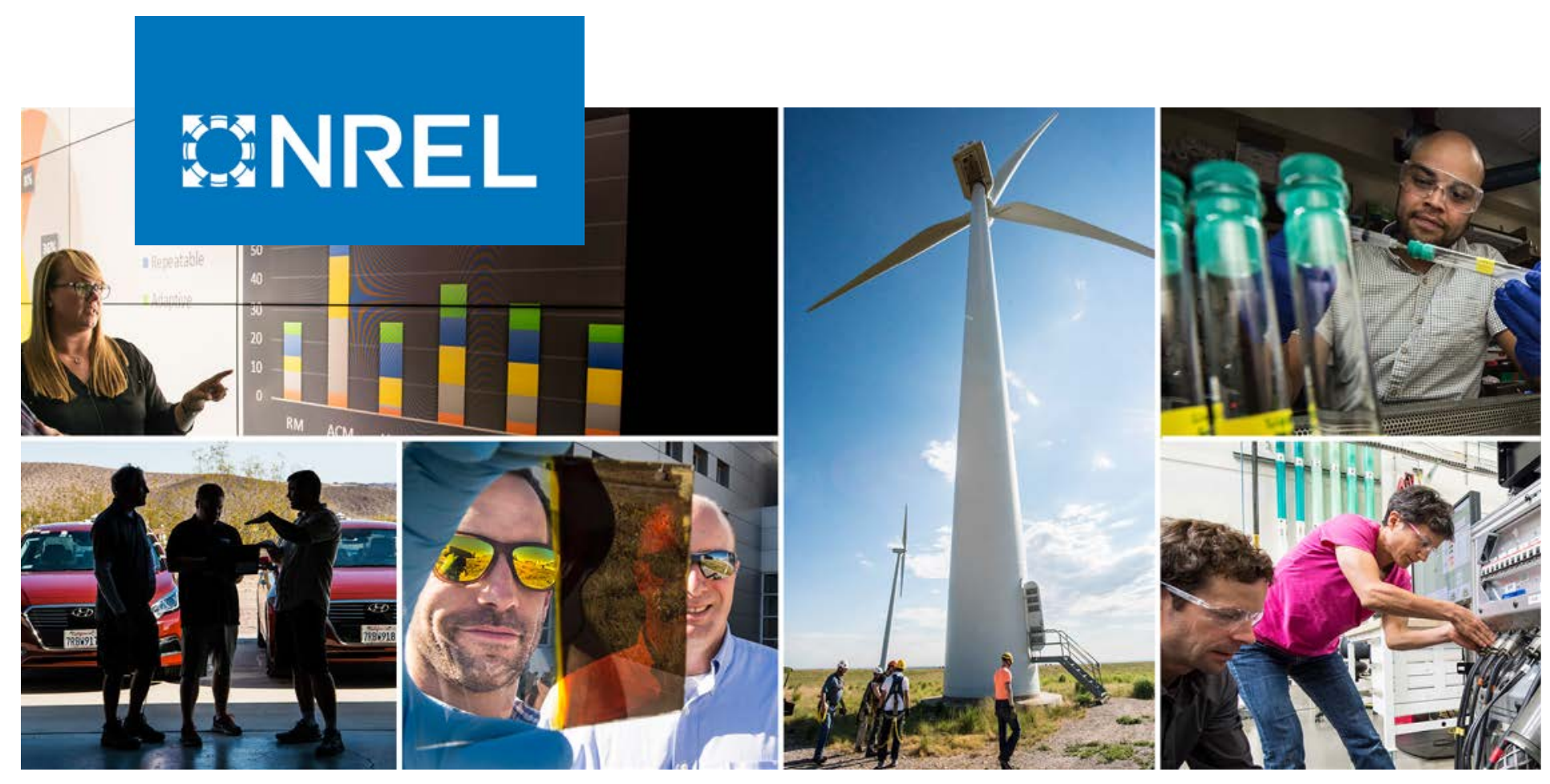

\title{
Electrification of Aircraft: Challenges, Barriers, and Potential Impacts
}

Amy Schwab, Anna Thomas, Jesse Bennett, Emma Robertson, and Scott Cary

National Renewable Energy Laboratory

NREL is a national laboratory of the U.S. Department of Energy Office of Energy Efficiency \& Renewable Energy

Operated by the Alliance for Sustainable Energy, LLC

This report is available at no cost from the National Renewable Energy Laboratory (NREL) at www.nrel.gov/publications.

\section{Technical Report}

NREL/TP-6A20-80220

October 2021 


\title{
GNREL
}

\section{Electrification of Aircraft: Challenges, Barriers, and Potential Impacts}

\author{
Amy Schwab, Anna Thomas, Jesse Bennett, \\ Emma Robertson, and Scott Cary
}

National Renewable Energy Laboratory

\section{Suggested Citation}

Schwab, Amy, Anna Thomas, Jesse Bennett, Emma Robertson, and Scott Cary. 2021.

Electrification of Aircraft: Challenges, Barriers, and Potential Impacts. Golden, CO:

National Renewable Energy Laboratory. NREL/TP-6A20-80220.

https://www.nrel.gov/docs/fy22osti/80220.pdf.

NREL is a national laboratory of the U.S. Department of Energy Office of Energy Efficiency \& Renewable Energy Operated by the Alliance for Sustainable Energy, LLC

This report is available at no cost from the National Renewable Energy Laboratory (NREL) at www.nrel.gov/publications.

Contract No. DE-AC36-08GO28308
Technical Report

NREL/TP-6A20-80220

October 2021

National Renewable Energy Laboratory 15013 Denver West Parkway Golden, CO 80401

303-275-3000 • www.nrel.gov 


\section{NOTICE}

This work was authored by the National Renewable Energy Laboratory, operated by Alliance for Sustainable Energy, LLC, for the U.S. Department of Energy (DOE) under Contract No. DE-AC36-08GO28308 with internal funding provided by NREL. The views expressed herein do not necessarily represent the views of the DOE or the U.S. Government.

This report is available at no cost from the National Renewable Energy Laboratory (NREL) at www.nrel.gov/publications.

U.S. Department of Energy (DOE) reports produced after 1991 and a growing number of pre-1991 documents are available free via www.OSTI.gov.

Cover Photos by Dennis Schroeder: (clockwise, left to right) NREL 51934, NREL 45897, NREL 42160, NREL 45891, NREL 48097, NREL 46526.

NREL prints on paper that contains recycled content. 


\section{Acknowledgments}

This work was supported by the U.S. Department of Energy (DOE) under Contract No. DEAC36-08GO28308 with the National Renewable Energy Laboratory (NREL).

The authors thank the NREL supporters of this project: Doug Arent for supporting the initial research into this topic, and Adam Warren, Dan Bilello, and Emily Newes for reviewing and supporting this report. The authors appreciate David Fleckenstein and T.S. "Max" Platts and their staff at the Washington State Department of Transportation Aviation Division for allowing us the opportunity to preview and comment on their Washington State study and thank them, along with David Ulane from the Colorado Department of Transportation, for reviewing this final report. The authors appreciate ICAO for permitting us to replicate the Appendix table of aircraft manufacturers. We especially thank Mike Meshek and Madeline Geocaris for their editorial and graphics support of this project.

The views expressed herein do not necessarily represent the views of the DOE or the U.S. Government. 


\section{List of Acronyms and Abbreviations}

$\begin{array}{ll}\text { ALS } & \text { San Luis Valley Regional Airport } \\ \text { Btu } & \text { British thermal units } \\ \text { CDR } & \text { Chadron Municipal Airport } \\ \text { CEZ } & \text { Cortez Municipal Airport } \\ \text { CLEEN } & \text { Continuous, Lower Energy, Emissions, and Noise } \\ \text { DEN } & \text { Denver International Airport } \\ \text { EIA } & \text { U.S. Energy Information Administration } \\ \text { FAA } & \text { Federal Aviation Administration } \\ \text { kg } & \text { kilogram } \\ \text { kW } & \text { kilowatt } \\ \text { kWh } & \text { kilowatt-hour } \\ \text { MCK } & \text { McCook Ben Nelson Regional Airport } \\ \text { MMmt } & \text { million metric tons } \\ \text { mph } & \text { miles per hour } \\ \text { MW } & \text { megawatts } \\ \text { NREL } & \text { National Renewable Energy Laboratory } \\ \text { PAX } & \text { number of passengers carried by an airline } \\ \text { PMT } & \text { passenger miles traveled } \\ \text { VTOL } & \text { vertical takeoff and landing }\end{array}$




\section{Executive Summary}

Though a National Academies of Sciences, Engineering, and Medicine study (National Academies 2016) suggests large all-electric commercial aircraft might not become viable until mid- to late- century, early stages of aircraft electrification are already underway. Small-scale electric and hybrid aircraft are under development, with small e-aircraft already certified to fly and with test flights underway for retrofits of existing aircraft (Boyle 2019) focused on near-term deployment. Internationally, as of February 2020, approximately 170 electric aircraft projects were underway, up 50\% since April 2018 (Selkirk 2020). These technologies are projected to increase operational efficiency and reduce emissions and noise from a growing aviation sector. A June 2020 National Academy of Engineering article (Langford and Hall 2020) echoes the National Academies (2016) study saying, "there is reason to be cautiously optimistic about the future of EAP [electrified aircraft propulsion]."

Emerging interest in aviation electrification includes interest from manufacturers of aircraft, energy supply equipment, and battery storage. And federal agencies are funding various efforts, including technology research as well as forecasting demand and environmental impacts. State governments have also begun pushing for further investigation in this area. For example, Washington State conducted a regional study to propose locations for charging infrastructure for small commercial electric aircraft to improve mobility for underserved communities.

This report provides an overview of the current state and potential future development of aviation electrification. To understand the types of research questions about current and future challenges for this emerging sector, we consider a case study of the potential deployment of small commercial electric aircraft for existing underserved markets and we consider operational requirements and technical challenges as well as the range of questions about charging infrastructure, grid integration, policy and regulatory requirements, and emissions impacts that will need to be addressed. The case study also outlines potential nearer-term solutions and research areas of interest that will need to be addressed in the longer term at much larger scales, and it highlights the National Renewable Energy Laboratory's capabilities for addressing these challenges with a variety of stakeholders. 


\section{Table of Contents}

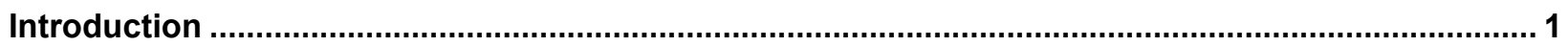

Motivations and Interest in Aircraft Electrification ...................................................................... 5

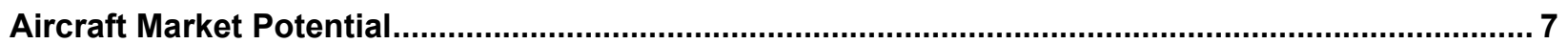

Trajectory of Electrified Aviation Development ............................................................................ 7

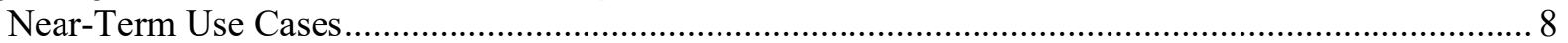

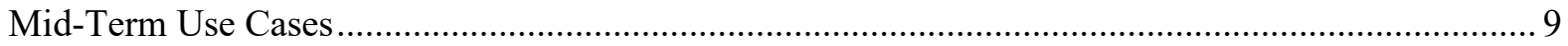

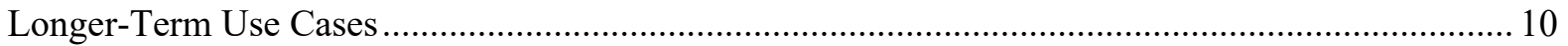

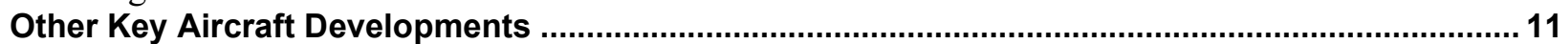

Battery Technology and Charging Infrastructure ...................................................................... 12

Electric Aviation Impacts on Airports ......................................................................................... 13

Case Study: Electrifying Routes within 300 Miles of Denver International Airport ........................ 15

Conclusions and Future Research........................................................................................ 23

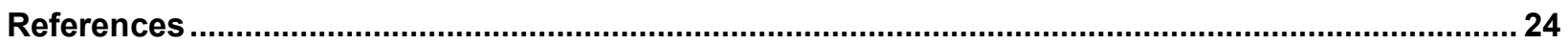

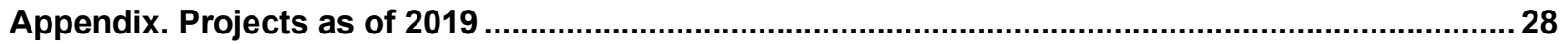




\section{List of Figures}

Figure 1. U.S. passenger air travel demand and energy intensity ........................................................ 3

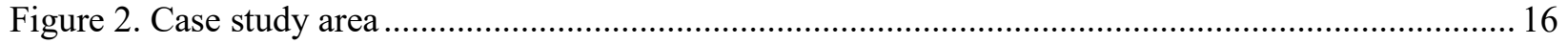

Figure 3. 2019 schedule of flights between DEN and ALS, CDR, CEZ, and MCK …........................... 20

Figure 4. Transmission capacity and substations near Denver International Airport .............................. 21

Figure 5. Transmission lines and substations near Chadron, Nebraska, airport ...................................... 22

Figure 6. Integrated energy requirements of future airports ............................................................. 23

\section{List of Tables}

Table 1. Development Trajectory of Aircraft Electrification. 8 Table 2. Essential Air Service Subsidies (2019-2022) a and 2019 Enplanements for Markets Served within 250 Miles of Denver International Airport ............................................................................ 16

Table 3. Information for Select Flights from Denver (DEN) for Liquid-Fueled and Electric Aircraft ...... 18 Table A-1. Electric Aviation Projects as of 2019 ................................................................................ 28 


\section{Introduction}

Aircraft accounted for an estimated 9\% of U.S. transportation energy consumption in 2019 (Davis and Boundy 2020). Though this portion is fairly small, in 2019, the U.S. Energy Information Administration (EIA) projected that air would be the only transportation mode expected to see sustained growth in energy demand, increasing this percentage to $14 \%$ by 2050 , which represents annual growth of about $1.1 \% .{ }^{1}$ Figure 1 (page 3 ) shows a steady growth in air travel demand since 1970 , with the exception of periods of economic downturns. Revenue passenger miles have averaged over 3\% annual growth between 2009 and 2019, while airlines have managed to reduce air travel energy intensity (British thermal units/passenger mile) and to keep energy consumption flat by increasing the number of seats on each aircraft and maintaining passenger load factors above $80 \%$. However, this strategy is unlikely to provide further benefits. The recent economic downturn has deeply impacted near-term air travel, and in the longer term, it may slow this growth.

EIA projects a greater than $60 \%$ increase in commercial air travel seat miles between 2019 and 2050 with a corresponding $38 \%$ increase in energy use and a 12\% increase in energy efficiency in seat miles per gallon (EIA 2019). This equates to an increase from 1.3 to 1.7 billion barrels of oil per day. Globally, EIA projects even higher demand growth, with growth in commercial jet fuel consumption surpassing all other liquid transportation fuels and doubling consumption by 2050. More than half of this growth occurs in non-Organization for Economic Cooperation and Development countries (EIA 2019).

Current carbon dioxide $\left(\mathrm{CO}_{2}\right)$ emissions from commercial aviation are estimated to be 186

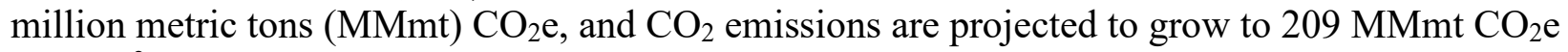
in $2050^{2}$. The aviation sector is considered difficult to decarbonize, and the primary alternative fuels are sustainable aviation fuels (SAF), which are primarily fuels derived from biomass sources. DOE goals for biofuels with a 50\% reduction of greenhouse gas over petroleum-derived fuels (DOE 2016) suggest SAF could potentially reduce $2050 \mathrm{CO}_{2} \mathrm{e}$ by $105 \mathrm{MMmt} \mathrm{CO}_{2} \mathrm{e}$ per year. $^{3}$

Recent industry economic downturns have generally resulted in aggressive retirement of inefficient aircraft with new acquisitions being focused on more efficient alternatives. Recent announcements regarding new aircraft orders appear to align 2020 pandemic airline responses with this trend. The current air travel disruption, with dramatic decreases in flights because of the COVID-19 pandemic and movement toward lower occupancy passenger vehicle options, could open opportunities for small, cost-effective, and reduced emissions aircraft by decreasing passenger loads (and potential virus exposure) while decreasing carbon emissions per mile

\footnotetext{
1 “Annual Energy Outlook 2018, Table 7: Transportation Sector Key Indicators and Delivered Energy Consumption," EIA, https://www.eia.gov/outlooks/aeo/data/browser/\#/?id=7-AEO2020\&region=0$\underline{0 \& \text { cases }}=$ ref $2020 \sim$ noace $\sim$ rpstranche 50 tx $\sim$ norps $\sim$ carbonfee $15 \sim$ carbonfee $25 \sim$ carbonfee $35 \&$ sourcekey $=0$

2,3 Percentage jet to total energy * CO2 emissions ("Annual Energy Outlook 2020, Table: Table 2. Energy Consumption by Sector and Source,” EIA https:/www.eia.gov/outlooks/aeo/data/browser/\#/?id=2$\underline{\mathrm{AEO} 2020 \& \text { cases }=\text { ref2020\&sourcekey }=0 \text {. }}$
} 
traveled and increasing frequency of air travel departure times that better align with traveler needs. 
Air Travel Demand

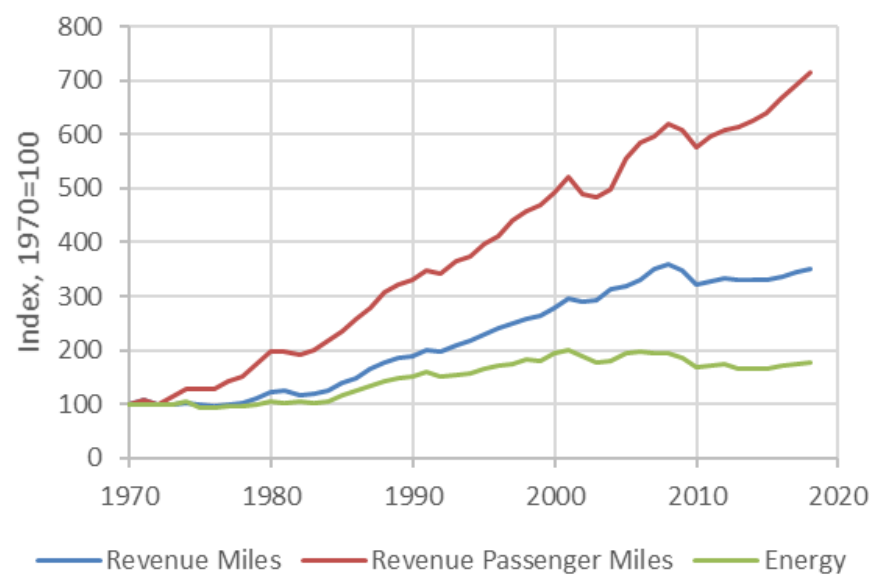

\section{Energy Intensity}

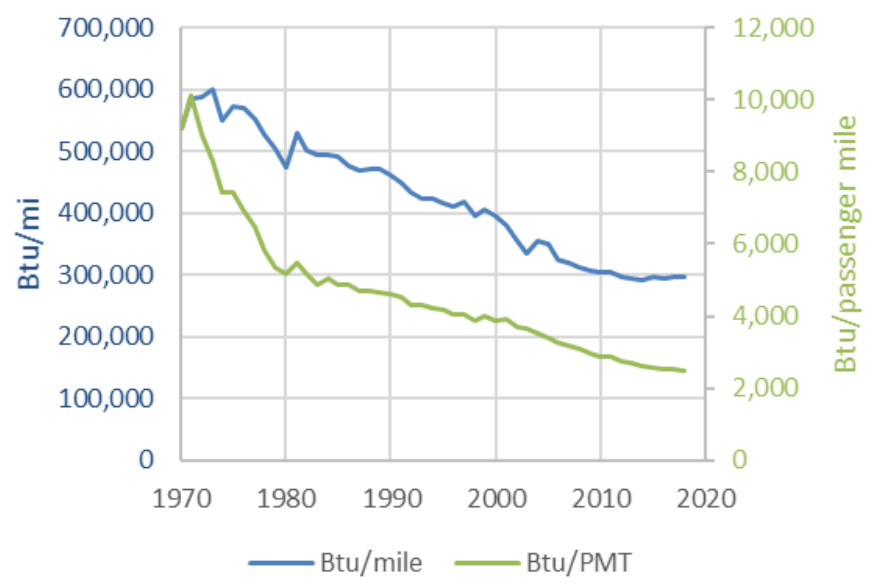

Energy Intensity, 1970-2018

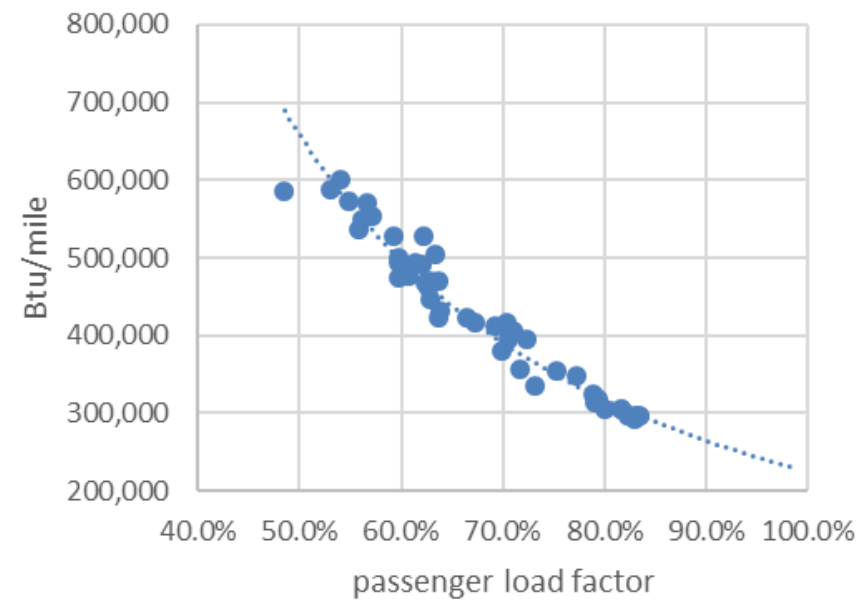

Figure 1. U.S. passenger air travel demand and energy intensity

Source: Davis and Boundy 2019

Btu $=$ British thermal units; $\mathrm{PMT}=$ passenger miles traveled

This report is available at no cost from the National Renewable Energy Laboratory (NREL) at www.nrel.gov/publications. 
Electrified aviation covers a wide range of aircraft types and varies in the extent of and approach to electrification. Classes of electrification include what we call here more electric, hybrid electric, and fully electric. In this report, we focus on the aircraft propulsion system independent of the guidance system, whether it is piloted, remotely managed (e.g., drone flight) or autonomous.

The more electric concept uses electric power for all nonpropulsive systems ${ }^{4}$ and focuses on modifying existing operations or systems to improve efficiency or on reducing work the engine has to do via aircraft or operational modification. Examples include using crewed electric tugs or pilot-controlled, guidable tugs to ferry aircraft to the runway end; using on-vehicle wheel motors for low-speed taxi; and maximizing use of ground power for avionics and aircraft climate control systems.

Hybrid electric propulsion includes systems that combine electric motors, battery storage, and other forms of aircraft energy generation to increase efficiency and reduce weight by decoupling thrust and power generation and/or providing focused thrust during key operational periods, allowing certain components to be optimized for cruising speeds. Arrangements include dualpropulsion aircraft with internal combustion engines augmented by electric motors. The electric motors can be powered by batteries providing energy from sources such as solar photovoltaic cells, hydrogen fuel cells, or a traditional gasoline or diesel generator. Prototype examples include Ampaire's Electric EEL, the Defense Advanced Research Projects Agency's XV-24A, and offerings by Pipistrel, Airbus, and Boeing and its subsidiaries.

Fully electric propulsion is currently viable for a wide range of aerial vehicles. Vehicle types include small, uncrewed vehicles, powertrain retrofits of existing fixed-wing aircraft, novel fixed-wing design configurations using electric motors, and vertical takeoff and landing (eVTOL) aircraft. Publicly announced aircraft in this category include Eviation's Alice, Beta Technologies' Alia-250, and Lilium Jet.

Electric aircraft applications span the full spectrum of current aircraft uses, including aerial survey and inspections for agriculture, disaster response, military logistics, and surveillance; flight training; recreation; delivery of high-value cargo such as critical medical shipments (e.g., samples and organs) and overnight delivery; and large-scale freight/cargo delivery. Passengerrelated applications include urban air mobility (e.g., Joby Aviation), military personnel movements, rural passenger access, remote community mobility (e.g., Alaska communities), regional commuter service, corporate travel, and large-scale commercial air service.

The electric aircraft market was estimated to be $\$ 99$ million in 2018 and is forecast to grow to $\$ 122$ million by 2023 (MarketsandMarkets n.d.). Some estimates suggest by 2040 this could grow to as much as $\$ 178$ billion (UBS 2019), with strong growth starting in 2028 when the first hybrid electric 50-70-seat aircraft is projected for delivery; this assumes more than 16,000 deliveries at an average price of about $\$ 11$ million.

\footnotetext{
4 “More Electric Aircraft (MEA): Next Generation Aircraft Power," https://moreelectricaircraft.com/.
} 


\section{Motivations and Interest in Aircraft Electrification}

Washington State released a feasibility study (WSDOT 2020) identifying key interested stakeholders in the electrification of aircraft including airports, public entities, aircraft operators, and manufacturers. Other state and local governments including the State of Colorado are exploring aviation electrification in various forms with studies and planned efforts to support this potential industry. In addition, the NASA Regional Air Mobility report (Antcliff et al. 2021) explored the potential market for electrifying small regional aircraft. The authors of that report recognized that not only is there a market for scheduled service but also a market for on-demand service and regional cargo, and that there is thus potential for increasing the overall market size. Utilities and regulators also have a significant interest in how this industry develops, especially in terms of planning for grid load growth in conjunction with broader electrification trends, infrastructure requirements to supply the peak demand from rapid high-capacity charging, and rate design considerations that accommodate the needs of new loads.

According to a recent market analysis (Howell Hanano n.d.), electrification of aircraft rests on a few main factors:

- Reduced Costs: Projected operational cost savings and lower long-term cost advantages represent the biggest motivation for aircraft operators and producers to electrify aircraft. For example, Ampaire projects its 15 -passenger aircraft would decrease fuel costs by $90 \%$ and reduce maintenance costs by $50 \%$. Such lower cost structures could provide an opportunity to revitalize service on routes that are not currently economical. Electric aircraft also promise reduced maintenance, lower noise on take-off and landing, and reduced carbon and other emissions. For example, Ampaire suggests 60\% quieter takeoffs and landings while eliminating tailpipe-emissions ${ }^{5}$ (excluding energy generation emissions), which are important in high-density population areas.

- Regional Travel Market: Regional markets, which are defined as markets in which trips are less than $500 \mathrm{~km}$ ( $\sim 310$ miles), are expected to lead growth for electric hybrid planes. This is because of the limited battery capacity of current technology and the new economic viability of serving these routes. Many of these routes operate out of a small percentage of airports, leaving many regional airports underutilized. The NASA Regional Air Mobility report (Antcliff et al. 2021) indicates that only $30(0.6 \%)$ of the 5,050 U.S. airports available for public use support $70 \%$ of domestic air travel. Currently uneconomical regional destinations, which are estimated at an additional 5,000 8,000 public and private use airports, may be served profitably with electric aircraft (Howell Hanano n.d.). Increasing traffic to these airports will also increase access to flights and reduce passenger travel time to the airport. According to McKinsey, $90 \%$ of the United States population is within a 30minute drive of a regional airport, compared to only $60 \%$ of the population within the same distance of a commercial airport ${ }^{6}$. Also, the cost of federal subsidies to maintain essential air service reaching small communities provides motivation to reduce the cost of air access to underserved communities. Unprofitable legacy service routes are currently subsidized by the federal government to maintain scheduled air service and the associated economic benefits of connected mobility. In 2020, \$326

\footnotetext{
${ }^{5}$ Ampaire website. Accessed August 2021. https://www.ampaire.com/

${ }^{6}$ Mckinsey Article. Accessed August 2021. https://www.mckinsey.com/industries/aerospace-and-defense/ourinsights/future-air-mobility-blog/right-in-your-backyard-regional-airports-are-an-accessible-and-underusedresource-for-future-air-mobility
} 
million in subsidies were distributed to 168 U.S. communities to maintain access by offsetting the cost of operating these routes (USDOT 2021).

- Emissions Reductions: Emissions reductions are a major driver of implementation of electric aviation worldwide. While a combination of technologies involving drop-in replacement fuels such as SAF will improve emissions, a particularly strong area for improvement is in flights in the regional travel market. Short haul aircraft are considered to be up to $50 \%$ less efficient than long-haul flights based on emissions (Baumeister, Leung, and Ryley 2020).

- Noise Reduction: The NASA Regional Air Mobility report (Antcliff et al. 2021) cite noise and potential emissions as factors in local communities' resistance to new airports and expanded air service. Regional electric aircraft have the potential to reduce the noise because of both the electric motor and steep climb/descent profiles of electric aircraft. According to Collins Aerospace (White 2020), internal United Technologies Corporation studies indicate that commercial hybrid-electric and electric propulsion could reduce aircraft noise up to $85 \%$ (electric), improve fuel consumption by $40 \%$ (hybrid), reduce $\mathrm{CO}_{2}$ emissions by more than $20 \%$ (hybrid), and reduce airline operating and maintenance costs up to $20 \%$ (electric and hybrid).

- Increased Accessibility: In addition to reducing emissions by switching air travel to clean electric power, encouraging a transportation mode shift away from ground transport for regional destinations could also reduce congestion and vehicle parking requirements at airport hubs for those accessing larger markets. For travelers to and from rural areas, electric aviation could provide an economical, clean alternative while reducing travel time and costs.

- Economic Development: According to the Washington State study (WSDOT 2020), airports and public entities are primarily interested in the potential for electric aviation to spur economic development by serving currently underserved areas, opening markets that have been phased out, repurposing general aviation airports to defray operational costs, and enhancing pilot training operations for colocated trade schools. There is also considerable interest in supporting emerging technology and innovation.

Environmental justice issues also drive interest in this area. Environmental justice concerns are triggered by human health or environment effects, including interrelated social and economic effects with displacement (e.g., of people and businesses), which are the most likely significant environmental justice issue at and around airports, and noise and air quality, which are the most likely environmental issues (FAA 2018).

Other benefits of electrified aviation include reducing the cost of pilot training (a significant factor in mitigating pilot shortages) and the ability to provide critical community services such as medevac services, organ delivery, and critical cargo delivery. 


\section{Aircraft Market Potential}

Major original equipment manufacturers predict around 10,000 nine-passenger aircraft will need to be replaced, assuming no market expansion. If lower-cost operations enable more regional market routes, according to Kevin Noertker, CEO of Ampaire, "the most conservative groups are saying double the number of aircraft needed," and some estimates suggest a tenfold increase in the number of aircraft (Howell Hanano n.d.).

With roughly $45 \%$ of global flights being under 500 miles, almost half of all flights are within the range of electric aircraft projected to be commercially available by 2030 (Downing 2019). Electric and hybrid-electric aircraft are projected to operate at $85 \%-90 \%$ efficiency and to be 20\%-40\% more efficient than piston and turbine aircraft (WSDOT 2019). The U.S. aviation industry contributes $12 \%$ of all carbon emissions (Downing 2019), which suggests electrification could have a large impact on decarbonizing the aviation sector.

\section{Trajectory of Electrified Aviation Development}

The electrified aviation industry is rapidly evolving. Electric aircraft are being developed across the range of aircraft types and uses; one small electric aircraft is already on the market, and other smaller electric aircraft have already been demonstrated. Siemens projects that:

- Because certification for ultralight aircraft and military aircraft will be less strict, these aircraft will be the first to market, in 2022.

- Larger-capacity scheduled flights on hybrid aircraft that require stricter certification will follow, by 2030.

- Electric propulsion will be the standard solution for all aircraft segments by 2050 (Howell Hanano n.d.).

Table 1 (page 7) shows the near-term to long-term technology horizons, the potential trajectory of aircraft development including use cases, descriptions of aircraft projected for uses, companies currently developing aircraft for those uses, and their current size. 
Table 1. Development Trajectory of Aircraft Electrification

\begin{tabular}{|c|c|c|c|c|}
\hline Timing & Use case & Description & \multicolumn{2}{|l|}{ Companies } \\
\hline \multirow{2}{*}{$\begin{array}{c}2020- \\
2025\end{array}$} & Pilot Training & $\begin{array}{l}\text { - } 1 \text { pilot and } 1 \text { passenger } \\
\text { - Cruise speed: } \sim 125 \mathrm{mph}\end{array}$ & \multicolumn{2}{|c|}{$\begin{array}{l}\text { - Pipistrel } \\
\text { - Bye Aerospace } \\
\text { - Rolls-Royce }\end{array}$} \\
\hline & $\begin{array}{l}\text { General } \\
\text { Aviation } \\
\text { /Personal } \\
\text { and Business }\end{array}$ & $\begin{array}{l}\text { - } 1-6 \text { passengers } \\
\text { - Average flight time: } 43 \text { minutes }\end{array}$ & $\begin{array}{l}\text { - Pipistrel } \\
\text { - Bye Aer }\end{array}$ & ace \\
\hline \multirow{3}{*}{$\begin{array}{c}2025- \\
2040\end{array}$} & $\begin{array}{l}\text { Regional } \\
\text { Commuter } \\
\text { ( }<5 \\
\text { passengers) }\end{array}$ & $\begin{array}{l}\text { - Air taxi under } 20 \text { miles } \\
\text { - Up to } 4 \text { passengers and } 1 \text { pilot } \\
\text { - Closer to } 50 \text {-mile range (eVTOL) }\end{array}$ & $\begin{array}{l}\text { - Joby } \\
\text { - Bell } \\
\text { - Hyundai } \\
\text { - Jaunt } \\
\text { - Archer }\end{array}$ & $\begin{array}{l}\text { - Lillium } \\
\text { - Elios } \\
\text { - Beta } \\
\text { Technologies } \\
\text { - Many others } \\
\text { (Blain 2020) }\end{array}$ \\
\hline & $\begin{array}{l}\text { Light Air } \\
\text { Cargo }\end{array}$ & $\begin{array}{l}\text { - Maximum payload: } 7,500 \text { pounds } \\
\text { - Cruise speed: } \sim 200 \mathrm{mph} \\
\text { - Custom cargo deliveries (e.g., United } \\
\text { Parcel Service, medical products, and } \\
\text { military) }\end{array}$ & \multicolumn{2}{|c|}{$\begin{array}{l}\text { - Ampaire } \\
\text { - magniX } \\
\text { - Beta Technologies }\end{array}$} \\
\hline & $\begin{array}{l}\text { Regional } \\
\text { (<15 } \\
\text { passengers) }\end{array}$ & $\begin{array}{l}\text { - Up to } 15 \text { passengers for scheduled } \\
\text { and/or unscheduled } \\
\text { operations/Federal Aviation } \\
\text { Administration (FAA) Part } 121 \\
\text { Commuter air service }\end{array}$ & \multicolumn{2}{|c|}{$\begin{array}{l}\text { - Ampaire } \\
\text { - Eviation (Reid 2019); } \\
\text { Siemens/magniX (2022) } \\
\text { - magniX }\end{array}$} \\
\hline $\begin{array}{c}2040- \\
2050\end{array}$ & $\begin{array}{l}\text { Commercial } \\
\text { Aircraft }\end{array}$ & - 186-seat electric aircraft & \multicolumn{2}{|c|}{ - Wright/EasyJet (2030) } \\
\hline
\end{tabular}

\section{Near-Term Use Cases}

Near-term uses will be in pilot training, general aviation, and business with other applications becoming prevalent a few years later. The general aviation market currently has more than 200,000 aircraft. All-electric aircraft for pilot training are available now and can accommodate one pilot and one passenger at cruise speeds of $125 \mathrm{mph}$. Companies developing aircraft for these applications include Bye Aerospace and Pipistrel, whose Alpha Electro - an ultralight, two-passenger aircraft - is currently available and EASA certified. The Alpha Electro, which is powered by a $60-\mathrm{kW}$ motor with a $100-\mathrm{kg}, 21-\mathrm{kWh}$ battery that allows for 1 hour of flight, can cover almost 160 kilometers and be charged in roughly 1 hour (Walków and Moynihan 2019).

General aviation aircraft for personal, recreational, and business purposes will hold up to six passengers with an average flight time of under 1 hour. Both Pipistrel and Bye Aerospace are developing electric aircraft for this market (Blain 2020). Size and capacity of this initial use case appear to indicate existing fast-charging system technology can support these vehicles, with charge times that are slightly longer than those historically required for refueling. 
Also, NASA has developed a semi-electric aircraft using fuel cells to generate electric power, and it could be introduced into service by 2035 (Howell Hanano n.d.). In addition to the semielectric effort, NASA is currently developing the X-57 Maxwell, the agency's first all-electric experimental aircraft and its first crewed X-plane in two decades.

\section{Mid-Term Use Cases}

Projected mid-term applications include regional commuter/air taxis, light cargo, and regional scheduled air service. Regional commuter/air taxis, which include electric vertical take-off and landing (eVTOL) aircraft, range from under 20 miles up to 50 miles and can carry up to four passengers. Table 1 shows companies working in this area, including Bell, Hyundai, Archer, and Beta Technologies. In February 2021, United announced a partnership with Archer to (1) investigate short-haul electric aircraft opportunities for flights serving customers traveling from regional airports to United's hub locations and (2) support mobility needs in dense urban environments. Archer is expected to begin producing their four-passenger eVTOL in 2023 and to supply United with up to 200 aircraft that could begin service as early as 2024 (United 2021).

Light air cargo use cases will likely focus on custom cargo deliveries and military applications. Ampaire, Beta Technologies, and magniX, the main companies focused on this application, are also working on eVTOL and conventional aircraft and power plants for the regional market. In April 2021, United Parcel Service announced a partnership with Beta Technologies with plans to electrify some of their cargo routes. United Parcel Service also plans to purchase 10 of the Alia250 aircraft, which can carry 1,400 pounds at speeds up to 170 miles per hour for 250 miles. Beta Technologies is scheduled to deliver these vehicles in 2024 for aircraft that currently carry loads of 500-3,000 pounds (Holland 2021).

Regional commuter service uses include carrying up to 15 passengers for scheduled (FAA Part 121) and/or unscheduled operation, and commuter air service. Companies focused on this segment include Ampaire, Eviation (Siemens/magniX), and magniX. As an example, Eviation's Alice, a nine-passenger aircraft, is designed to fly up to 440 nautical miles (with an additional 45-minute reserve) at around 220 knots and is expected to make its first flight in 2021 with deliveries likely to occur in 2023 (Singh 2021). This aircraft is projected to be charged by $500-\mathrm{kW}$ chargers on mobile bowser trucks, and it is intended to mitigate initial infrastructure investments for the early adopters and support a full recharge in a little over 1 hour (Thurber 2019). In May 2020, a modified Cessna Caravan 208B, which can carry a maximum of nine passengers, completed a test flight powered by a magniX engine and thus became the biggest commercial plane ever to take off and fly by electricity alone (Baraniuk 2020). ${ }^{7}$

Charging mid-term use aircraft will require supply equipment with a charge rate of greater than $2 \mathrm{C}$, and, for the $820-\mathrm{kWh}$ (kilowatt-hour) Alice battery, a peak demand that could potentially exceed 2 megawatts (MW). These requirements exceed current light-duty ground vehicle battery and charging technologies, such as the Tesla Supercharger, which operates at charge rate of approximately $1 \mathrm{C}$ with a peak demand of approximately $250 \mathrm{~kW}$ (Hinman 2019).

\footnotetext{
${ }^{7}$ Zunum, a Boeing-backed firm that had targeted delivery of a hybrid aircraft for early 2020 (Intelligent Aerospace 2020) ran into financial issues in 2019 (Bogaisky 2019).
} 


\section{Longer-Term Use Cases}

In the longer term (2040-2050), development of commercial aircraft includes work on singleaisle aircraft with around 70 seats and electric/hybrid capabilities. These aircraft are slated to replace jets of the same class as the Bombardier Q400, Bombardier CRJ700, and Embraer EMB135. Wright/EasyJet is working on a 186-seat all-electric aircraft that is projected to be ready for testing in the 2030 time-frame. 


\section{Other Key Aircraft Developments}

Other notable players evaluating electric aircraft development include Airbus - with multiple technology pathways - which ended its E-Fan X effort that demonstrated the replacement of one jet engine with 2-MW electric motor; Rolls Royce (with Airbus on E-Fan X), which is developing an experimental single-seater due for flight in 2021 (Baraniuk 2020); Embraer; and Pratt \& Whitney. ${ }^{8}$ And consolidation has already begun in this sector, as various entities are moving to market and various technology developments are advancing or shifting focus. Also, the Federal Aviation Administration (FAA) is also actively investigating electrification of aviation; it is evaluating "urban air mobility" infrastructure requirements, including electrification infrastructure, all-hazards evaluations, geometric design, and related efforts using the National Renewable Energy Laboratory (NREL) and industry support.

In February 2020, the FAA Aviation Sustainability Center, or Ascent, awarded $\$ 300,000$ to the Massachusetts Institute of Technology for a comparative assessment of electrification strategies for aviation that analyzes the relative economic and environmental benefits of using (1) electricity to power future aircraft and (2) batteries or liquid fuels produced from electricity. They also awarded \$280,000 to Pennsylvania State University for an Urban Air Mobility Noise Reduction Modeling project to extend helicopter noise modeling to urban air mobility vehicles to identify means for noise reduction, although it is unclear whether this project will examine electrified air mobility vehicles.

In 2010, the FAA — with Boeing, General Electric (GE), Honeywell, Pratt \& Whitney (P\&W), and Rolls-Royce as cost-sharing partners - began the CLEEN (Continuous, Lower Energy, Emissions, and Noise) program. CLEEN projects are intended to develop technologies to reduce noise, emissions, and fuel burn and to enable the aviation industry to expedite integration of technologies into existing and future aircraft. ${ }^{9}$ As electrification of ground-based transportation matures in other states with strong emissions reductions goals (e.g., California, Massachusetts, and New York), we expect to see a stronger focus on aviation electrification.

\footnotetext{
${ }^{8}$ Table A-1 in the appendix presents a list of all-electric, hybrid, and hydrogen aircraft developers compiled in 2019 by the International Civil Aviation Organization.

9 "Continuous Lower Energy, Emissions, and Noise (CLEEN) Program," FAA, last modified July 7, 2021. https://www.faa.gov/about/office_org/headquarters_offices/apl/research/aircraft technology/cleen/.
} 


\section{Battery Technology and Charging Infrastructure}

Advanced battery technologies and charging infrastructure are the key components of electrifying a transportation fleet. Companies working specifically on charging infrastructure include Pipistrel, which is developing chargers for its own planes; Beta Technologies; ${ }^{10}$ and ElectroAero, which is developing a DC charging solution for this market (Randall 2019). ChargePoint introduced a 2-MW charge connector concept at the 2018 Uber Elevate conference. Start-up level entrepreneurs are also evaluating the promising opportunities related to charging infrastructure. Companies involved in automotive charging are expected to also begin looking at charging needs for electric aircraft.

The General Aviation Manufacturers' Association and SAE International committees are leading other industry efforts to standardize charging standards, including ports. Consensus among industry representatives, trade associations, NASA, and others indicates that energy delivery to the charger might need additional evaluation. Aircraft battery technologies being investigated, such as Eviation's Alice, include 820-kilowatt-hour (kWh) batteries. ${ }^{11}$ Battery capacities at that scale will likely require megawatt-level charging to support the rapid recharging currently required, for example, a full recharge in less than 30 minutes, which exceeds the current capabilities of the most powerful light-duty automotive-sector chargers (DOE n.d.).

Charging stations of this capacity will require solutions that consider the physical limitations of the charging infrastructure and energy storage device. These solutions may include parallel charging (i.e., charging from two separate battery banks), wireless charging (which poses an issue because of electromagnetic impacts on sensitive aviation and lightning arrest systems), and the use of nanoelectrofuel flow battery technology, where charging occurs by replacing battery fluids (Mackay 2019). Demonstrator nanoelectrofuel technology is being developed by Influit Energy with NASA funding (Sigler 2018). Issues being encountered include cable cooling, logistical challenges of hooking up charging cables, the need to keep charging infrastructure and/or battery packs on a mobile platform for parking and taxi flexibility, and electromagnetic shielding required for aircraft avionics.

Various promising charging and battery technologies are being explored by a wide variety of stakeholders and participants in the effort to electrify the aviation sector.

\footnotetext{
10 "Rapid Charging," Beta, https://www.beta.team/beta-home/recharging/.

11 "Alice Specifications." Eviation. https://www.eviation.co/aircraft/\#Alice-Specifications
} 


\section{Electric Aviation Impacts on Airports}

Though aircraft manufacturers are envisioning a new future of electrification, airports and airport operators are just starting to electrify their ground vehicles. While this is occurring, airports need to begin considering the electrical needs and long-term power demand required to meet the needs of future all-electric aircraft. Near-term efforts need to consider both electric aircraft and growing electrification of other airside and landside vehicles. For airports operating with significant intermodal cargo operations, the concentrated electrification occurring with last-mile delivery cargo vehicles, regional cargo aircraft, and regional passenger service will need to be evaluated against planned regional electrical capacity. Longer-term adoption (2030-2050) will be heavily influenced by early results, whether successes or failures.

The long lead times in utility and airport planning and in aircraft development provide time for coordination and planning of airside impacts. These impacts include electrical needs, including size, current power capabilities, and density of expected demand as well as trajectory from current operations to long-term needs. Especially considering long-term planning cycles, nearterm modifications should account for the potential that decreased costs of flying might increase overall air demand.

Airports often have much land that potentially could be used for distributed energy generation for existing airport operations, for charging electric aircraft, and even for other community uses when aircraft charging is not needed. Rural areas interested in improving air access as well as states with many such communities, might be interested in understanding how new distributed energy generation or excess local supply could be coupled with energy storage to meet the new potential energy demand. 


\section{Research and Development Needs for Aviation Electrification}

Further development and research in charging technologies will be needed to support the electrification of aviation. Aircraft batteries will require chargers with power ratings exceeding that of current technology and will most likely require airline-specific standards. Different manufacturers are working on this challenge, but no standard has yet been established. The large amount of current flowing through these devices suggests the need for thick conductors and robust charging couplers and might require active cooling to support the battery during quick charging sessions. Additionally, the grid impacts of these new loads, as well as the interconnection solutions that may be required, pose significant challenges that need to be investigated. As an alternative to conventional batteries, hydrogen technology could prove a denser energy storage option with the potential to reduce peak demand concerns. This could be achieved by producing hydrogen throughout the day through the process of electrolysis, enabling more rapid aircraft charging without creating a significant spike in electricity demand. Further analyses of these topics are needed to understand the full extent of charging stations on infrastructure requirements. These analyses could provide information about how much capacity may be required in various use cases. 


\section{Case Study: Electrifying Routes within 300 Miles of Denver International Airport}

Current electric aircraft technologies are being sized to serve a 500-mile range. With $45 \%$ of all current global airline flights (not including cargo) being under 500 miles, and 5\% being under 100 miles (Ansys 2020), short-haul flights represent the target market for companies hoping to electrify aviation within the next 10 years. With these advancements in aircraft technologies, work is needed to create the sustainable infrastructure to support aircraft charging in the nearer and longer term.

This case study illustrates some of the challenges associated with electrifying aviation on a small scale by focusing on four regional markets with service to Denver International Airport (DEN). These four markets are part of the federally funded Essential Air Service program, which subsidizes commercial air service for routes that are not currently profitable but are needed to serve remote communities. The flights of interest for this case study are those that are less than 300 miles from DEN: Alamosa, Colorado (ALS, 179 miles); McCook, Nebraska (MCK, 217 miles); Chadron, Nebraska (CDR, 222 miles); and Cortez, Colorado (CEZ, 277 miles). These markets access the broader global market via a hub (DEN) and spoke arrangement.

The case study focuses on a representative flight scheme mirroring existing demand and schedules as of fall 2020 and substituting electric aircraft for existing aircraft. Figure 2 (page 165) shows these flight paths as well as transmission lines around these airports that support the electrical needs of the adjacent communities; it provides an idea of how implementing allelectric aircraft may impact that area. Areas with a lower voltage class may require further electrical infrastructure depending on the extent to which electric aviation charging infrastructure will be implemented.

Table 2 outlines recent air service subsidies given to select locations within 300 miles of DEN. This illustrates the focus local and federal funders have on promoting use of and access to more underserved areas. The aim of these subsidies is to ensure enplanements and air travel accessibility for the local community; more effective economic business access to larger communities; and reduced need for long-distance, ground transportation modes to access air travel or more urban resources. 


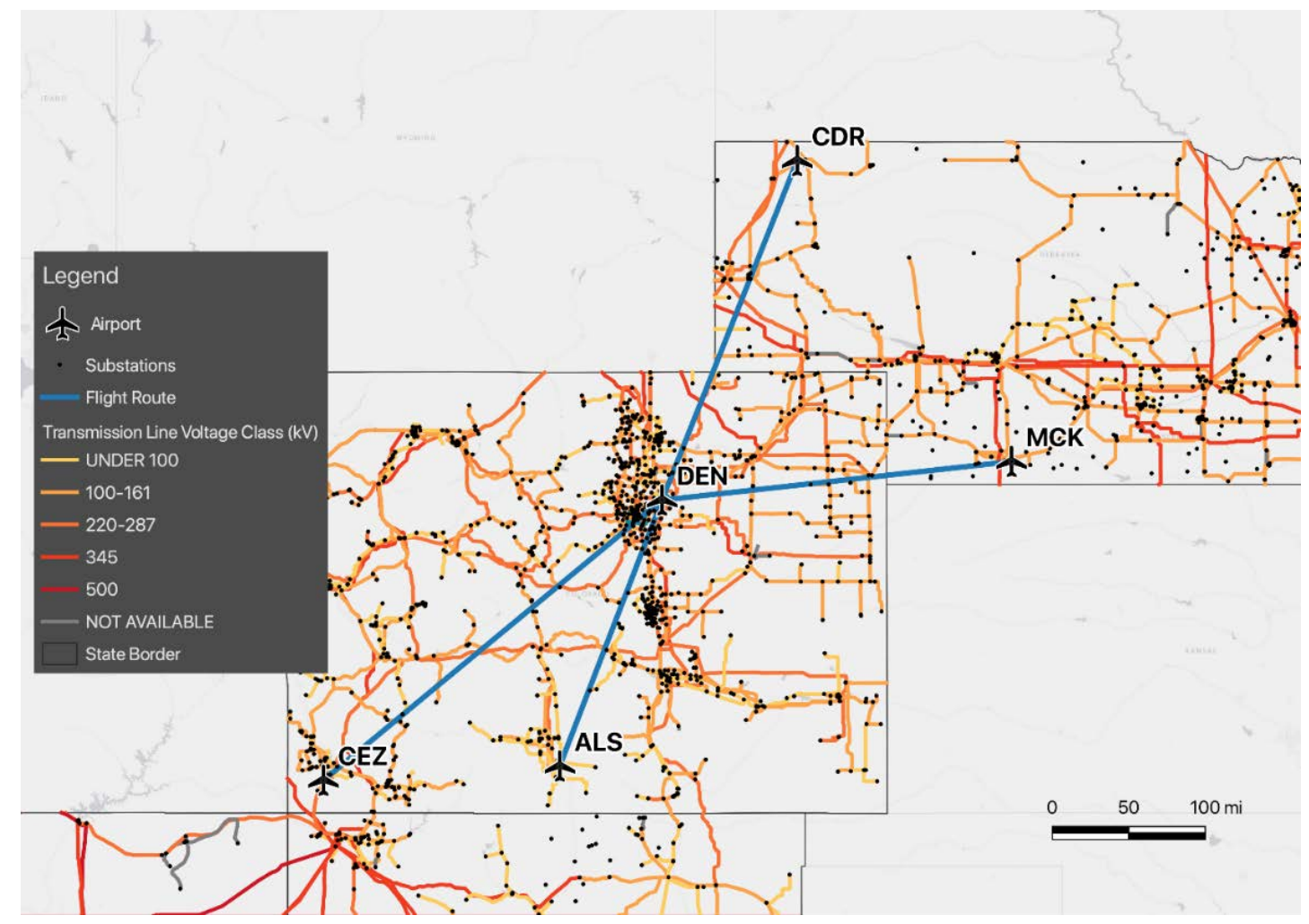

Figure 2. Case study area

Illustration by Emma Robertson, NREL

Table 2. Essential Air Service Subsidies (2019-2022) and 2020 Enplanements for Markets Served within 280 Miles of Denver International Airport

\begin{tabular}{cccccc} 
Airport $^{\mathrm{b}}$ & 2019 & 2020 & 2021 & 2022 & $\begin{array}{c}2020 \\
\text { Enplanements }\end{array}$ \\
\hline MCK & $\$ 2,462,456$ & $\$ 2,511,705$ & $\$ 2,561,939$ & $\$ 2,613,178$ & 1,269 \\
CDR & $\$ 2,456.787$ & $\$ 2,518,208$ & $\$ 2,737,716$ & $\$ 2,808,159$ & 2,462 \\
ALS & $\$ 2,891,307$ & $\$ 2,949,133$ & $\$ 3,505,574$ & $\$ 3,505,574$ & 4.742 \\
CEZ & $\$ 3,579,703$ & $\$ 3,669,195$ & $\$ 3,760,925$ & $\$ 3,854,948$ & 5,603 \\
\hline
\end{tabular}

a "Essential Air Service," Department of Transportation Accessed August 2021.

https://www.transportation.gov/policy/aviation-policy/small-community-rural-air-service/essential-airservice, accessed August 2021. Data for 2022:, MCK: USDOT 2018-5-10 Order Re-Selecting Air Carrier and Establishing Subsidy Rates; CDR: USDOT Order 2021-4-6 Selecting Air Carrier: file:///Users/aschwab/Downloads/DOT-OST-2000-8322-0160_attachment_2.pdf, ALS: USDOT 2020-917 Order Extending Contract, https://www.regulations.gov/document/DOT-OST-1997-2960-0193; CEZ: 2018-8-1 Order Re-Selecting Carrier and Establishing Subsidy Rates, https://www.regulations.gov/document/DOT-OST-1998-3508-0062

${ }^{\mathrm{b}} \mathrm{MCK}=$ McCook Ben Nelson Regional Airport; CDR = Chadron Municipal Airport, ALS = San Luis Valley Regional Airport; CEZ = Cortez Municipal Airport

c "Passenger Boarding (Enplanement) and All-Cargo Data for U.S. Airports," FAA, last modified August 12, 2021, https://www.faa.gov/airports/planning capacity/passenger allcargo stats/passenger/. 
Table 3 lists the flight details alongside their current fuel costs and projected electricity costs. The Pilatus PC-12 aircraft currently serving these flights has a standard 402-gallon fuel capacity, has a refueling rate of 66 gallons/minute, and holds $6-9$ passengers per flight. ${ }^{12}$ Projected electricity costs are based Eviation's Alice aircraft which could serve these routes in the future with a proposed $820-\mathrm{kWh}$ lithium-ion battery (nickel manganese cobalt) with three electric motors and a nine passenger capacity. ${ }^{13}$

\footnotetext{
12 "PC-12 NGX: The World's Greatest Single," Pilatus, https://www.pilatus-aircraft.com/en/fly/pc-12. 13 "Alice," Eviation, https://www.eviation.co/aircraft/\#4; see also "Industry-Leading Products," magniX, https://www.magnix.aero/products.
} 
Table 3. Information for Select Flights from Denver (DEN) for Liquid-Fueled and Electric Aircraft

\begin{tabular}{|c|c|c|c|c|c|c|c|c|c|c|}
\hline Destination & $\begin{array}{c}\text { Flights } \\
\text { Iday }\end{array}$ & Miles & $\begin{array}{c}\text { Flight } \\
\text { Time } \\
\text { (mins) }\end{array}$ & $\begin{array}{c}\text { Fuel Use } \\
\text { (gals) }\end{array}$ & $\begin{array}{c}\text { Fuel } \\
\text { Costs }^{a}\end{array}$ & $\begin{array}{l}\mathrm{kgCO}_{2} \\
/ \mathrm{PAX}\end{array}$ & $\begin{array}{c}\text { kWh } \\
\text { (approx.) }\end{array}$ & $\begin{array}{c}\text { Electricity } \\
\text { Costc }^{c}\end{array}$ & $\begin{array}{c}\mathrm{kgCO}_{2} \\
\text { /PAX } \\
\text { Coalc,d }\end{array}$ & $\begin{array}{c}\mathrm{kgCO}_{2} \\
\text { /PAX } \\
\text { Solar }^{\mathrm{c}, \mathrm{c}}\end{array}$ \\
\hline ALS & 4 & 179 & 80 & 88 & $\$ 440$ & 36 & 334 & $\$ 43$ & 34 & 2 \\
\hline CEZ & 3 & 277 & 80 & 88 & $\$ 440$ & 56 & 516 & $\$ 66$ & 53 & 3 \\
\hline MCK & 2 & 217 & 65 & 72 & $\$ 358$ & 44 & 404 & $\$ 52$ & 41 & 2 \\
\hline CDR & 2 & 222 & 70 & 77 & $\$ 385$ & 44 & 414 & $\$ 53$ & 42 & 2 \\
\hline
\end{tabular}

a Assuming a $\$ 5 /$ gallon fuel cost 14

${ }^{b} \mathrm{PAX}=$ number of passengers carried by an airline, assuming eight passengers.

c Based on commercial electricity costs for Cortez, Colorado; these values provide a conservative estimate of the electricity costs. Industrial electricity cost pricing could provide a $50 \%$ reduction in these costs.

${ }^{\mathrm{d}} \mathrm{kg} \mathrm{CO} 2$ calculated from the use of coal and utility scale solar to produce the needed amount of energy ("IPCC Working Group III - Mitigation of Climate Change, Annex II Metrics and Methodology" IPCC https://www.ipcc.ch/site/assets/uploads/2018/02/ipcc_wg3_ar5_annex-ii.pdf\#page=26).

14 "Fuel Price Report: Summary of Fuel Prices at 3662 FBOs Nationwide." Accessed September 14, 2021. https://www.airnav.com/fuel/report.html. Retail pricing. Wholesale pricing has been reported at up to a $60 \%$ discount at hub locations. 
The data in Table 3 show the important role electric aviation could have in reducing both the costs and $\mathrm{CO}_{2}$ emissions required for commercial air travel. Replacing the current Pilatus PC-12 aircraft with an Eviation Alice could reduce per flight fuel cost from approximately $\$ 400$ to around $\$ 50$ and could reduce $\mathrm{CO}_{2}$ emissions as much as $95 \%$. Electric airplanes, much like battery electric vehicles, have lower operational energy costs as a result of electric drivetrain efficiencies and the lower cost of electricity, subject to demand and availability charges. Using electricity would also reduce the $\mathrm{CO}_{2}$ emissions associated with air travel, even for regions powered entirely by coal. Considering both these benefits are complemented by reduced electric vehicle maintenance and further emissions reductions from renewable energy, electric aviation should enable lower-cost and more accessible travel.

To implement all-electric aircraft, airports must consider the dwell time available for plane recharging, as well as coincidence charging that may likely occur at higher-traffic (i.e., hub) airports. Current route schedules for the four airports studied have turnaround times of approximately 20-30 minutes for potential refueling. To mirror current desired energy transfer rates, each aircraft would require charging stations capable of delivering an average power of around $1 \mathrm{MW}$, which exceeds the abilities of current market options. Current light-duty automobile technologies offer fast charging with power ratings of up to $250-350 \mathrm{~kW}$ and unit costs exceeding $\$ 100,000$ per charger (Burns \& McDonnell 2019.). Each of the flights in this case study consume 300-500 kWh (Table 3), and would need to fully recharge in less than 30 minutes to accommodate existing flight schedules. To fully recharge the Eviation Alice's 820$\mathrm{kWh}$ battery within current dwell periods would likely require a power rating of $2 \mathrm{MW}$ or more. This estimated power requirement also does not consider the charging profiles for DC fast chargers, which have a reduced load factor and consequently a higher peak demand, which is of concern when considering the infrastructure needed for a grid interconnection capable of serving these large loads. Our analysis assumes a grid connection and no energy storage.

The regional flight schedules for the four airports studied here each include just one plane servicing flights to and from Denver. We assume the highest concentration of charging will occur at the hub in Denver, resulting in the potential for a large coincident charging peak. Understanding such coincident peaks will be crucial in understanding the peak demand at each airport, and consequently, the infrastructure needed to supply that load. Figure 3 illustrates the arrival and departure times into and out of DEN by current flights to the four destinations. Assuming charging will occur immediately following arrival, a potential charging peak of $4 \mathrm{MW}$ could occur at multiple times throughout the day because of planes landing within the same hour. Note at 8 A.M., 12 P.M., and 6 P.M., flights are landing and subsequently taking off within an hour, requiring fast charging technologies. This is illustrative of one small carrier operating to only four locations. 


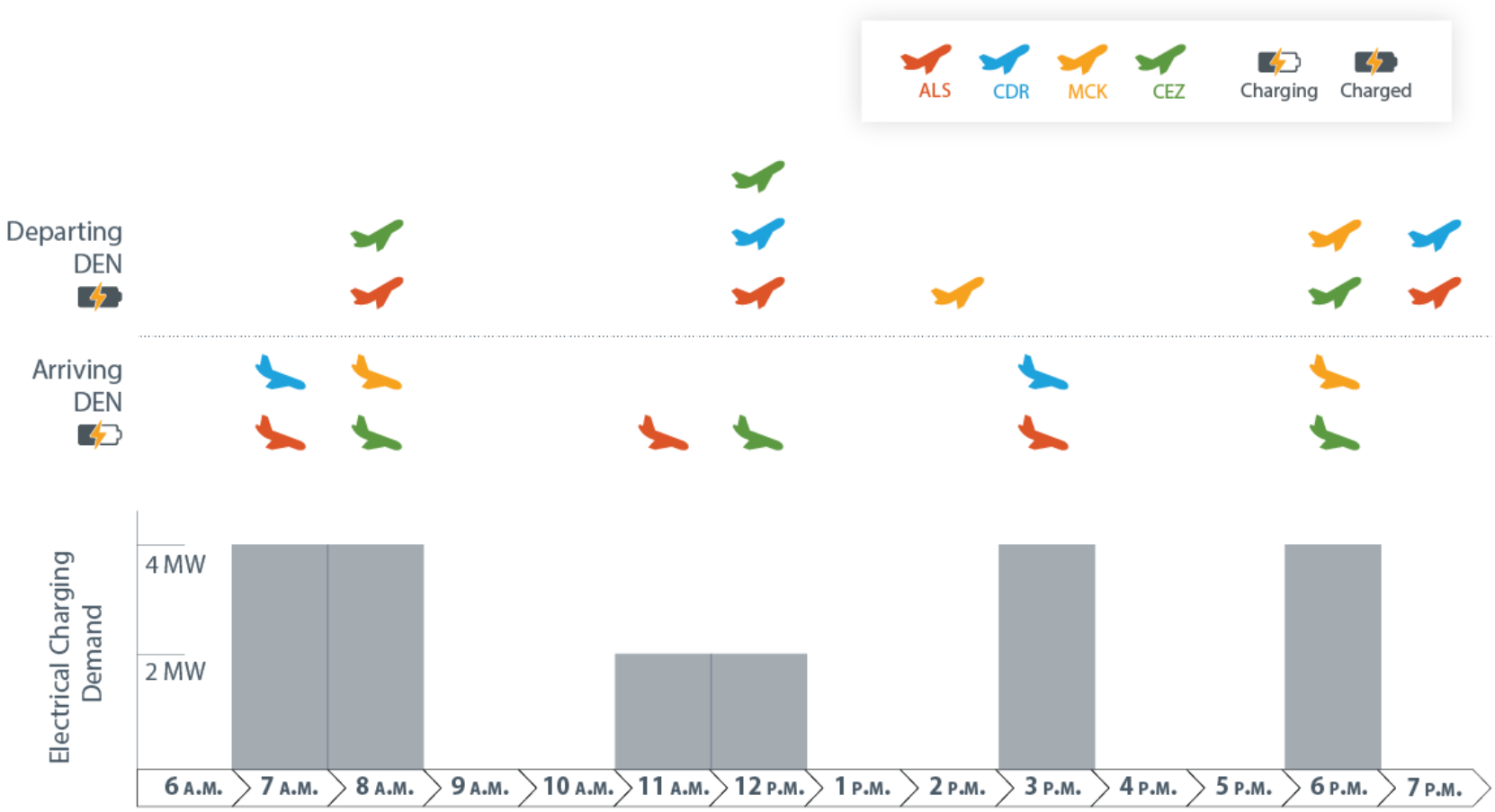

Figure 3. Potential load impacts of 2019 flight schedule between DEN and ALS, CDR, CEZ, and MCK

The peak demand at each airport impacts both the infrastructure requirements and the cost of electricity for electric aviation. Considering electricity loads for the airport as a whole, these charging stations would become one of the largest loads throughout the airport. Supporting new electric loads of 1-2 MW would require significant improvements to the electrical service equipment throughout the airport, including wiring and service panel upgrades. However, airports with higher coincident peaks requiring multiple charging stations exceeding 2-10 MW would potentially impact equipment interfacing with the electricity providers. For low-volume needs, impacts could require mobile delivery of energy, energy storage/generation, larger distribution service transformers, or upgraded primary line conductors. Should stationary or mobile battery-based storage systems be used to meet desired power ratings, the overall energy requirement could remain the same; however, peak energy requests could be more evenly requested although likely at higher infrastructure cost. But this could also create the need for substation capacity expansion or the installation of a new distribution line, both of which would be of less concern for airports close to substations.

As electric aviation grows and an airport's peak charging demands increase to $20 \mathrm{MW}$ or more, loads on the system could exceed the capacity of local distribution systems and push the need for the airport to become a transmission partner. To put this demand into perspective, a 20-MW increase in demand represents approximately a $25 \%$ increase for a large hub airport such as Dallas Fort Worth International Airport. Concurrent with such additional loads from aircraft electrification are colocated additional loads requested by cargo operators to meet the needs for electrifying last-mile cargo delivery (Domonoske 2021). This could necessitate infrastructure upgrades potentially exceeding $\$ 10$ million (NIT n.d.). Many utilities provide cost-sharing 
opportunities for such projects and these costs do not factor in the potential benefits of being a transmission partner such as wholesale energy pricing or potential revenue from providing ancillary grid services. Further research is needed to understand how different charging levels potentially impact infrastructure requirements, resiliency, flight schedules, and business strategies. Options such as smart charge management that may provide lower-cost solutions and limit the need for equipment upgrades need to be assessed against other operational considerations.

Figure 4 shows that Denver International Airport (DEN) is close to and serviced by numerous substations. DEN is provided with higher-voltage class transmissions lines than the more rural airports included in this case study. This makes DEN an interesting candidate for implementing charging infrastructure for proof-of-concept studies on electric aviation.

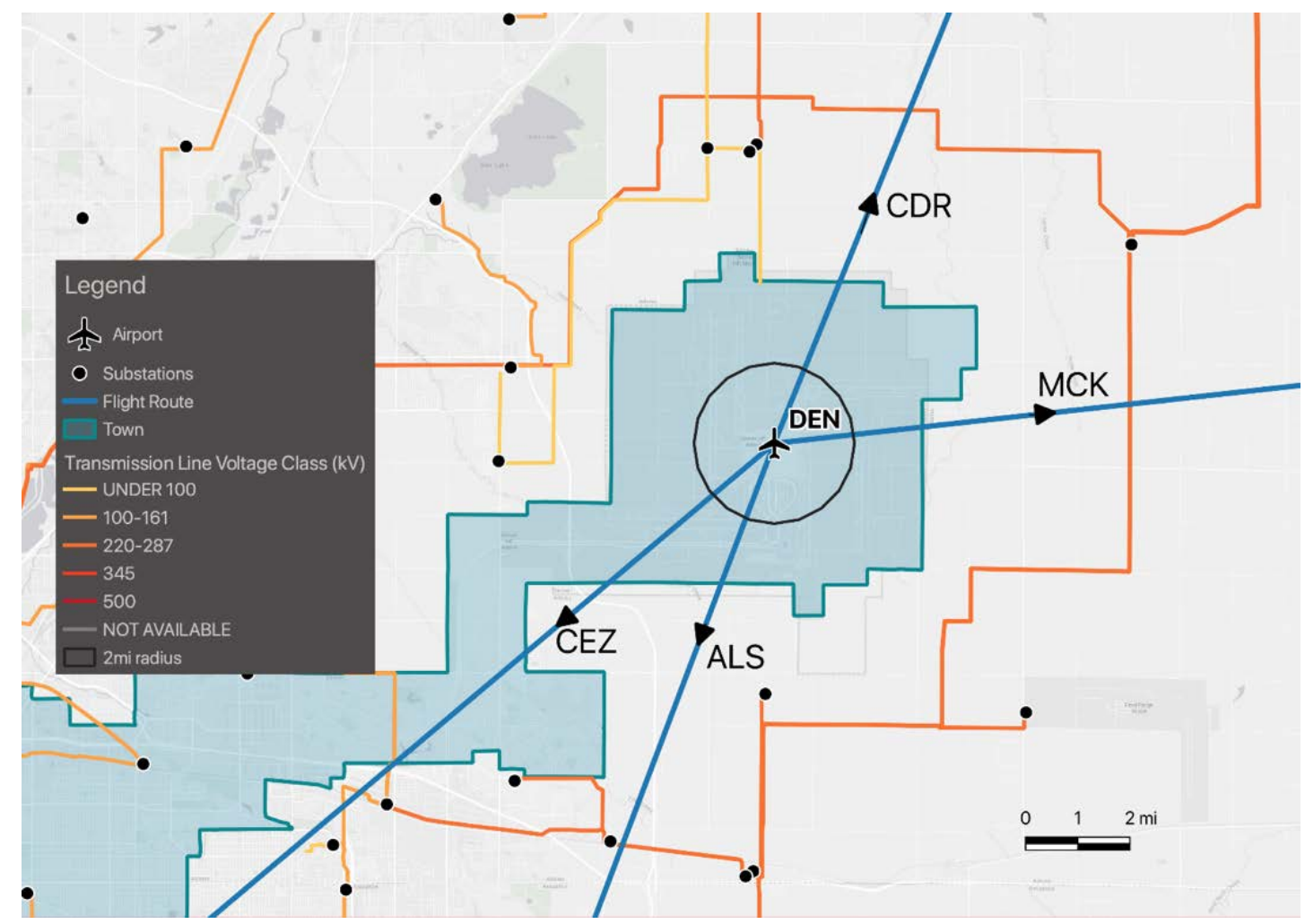

Figure 4. Transmission capacity and substations near Denver International Airport Illustration by Emma Robertson, NREL

Figure 5 shows that the airport in Chadron, Nebraska (CDR), is nearly six miles from the nearest substation with lower-voltage class transmission lines. Supporting broad adoption of electric aviation would require both electrical infrastructure improvements and longer-term studies of how to expand the electrical infrastructure at CDR to implement electric aviation. Initial charging of electric aircraft could possibly be served via mobile battery systems; however, updated infrastructure might provide additional benefits through, for example, more microgrid security for the region. 


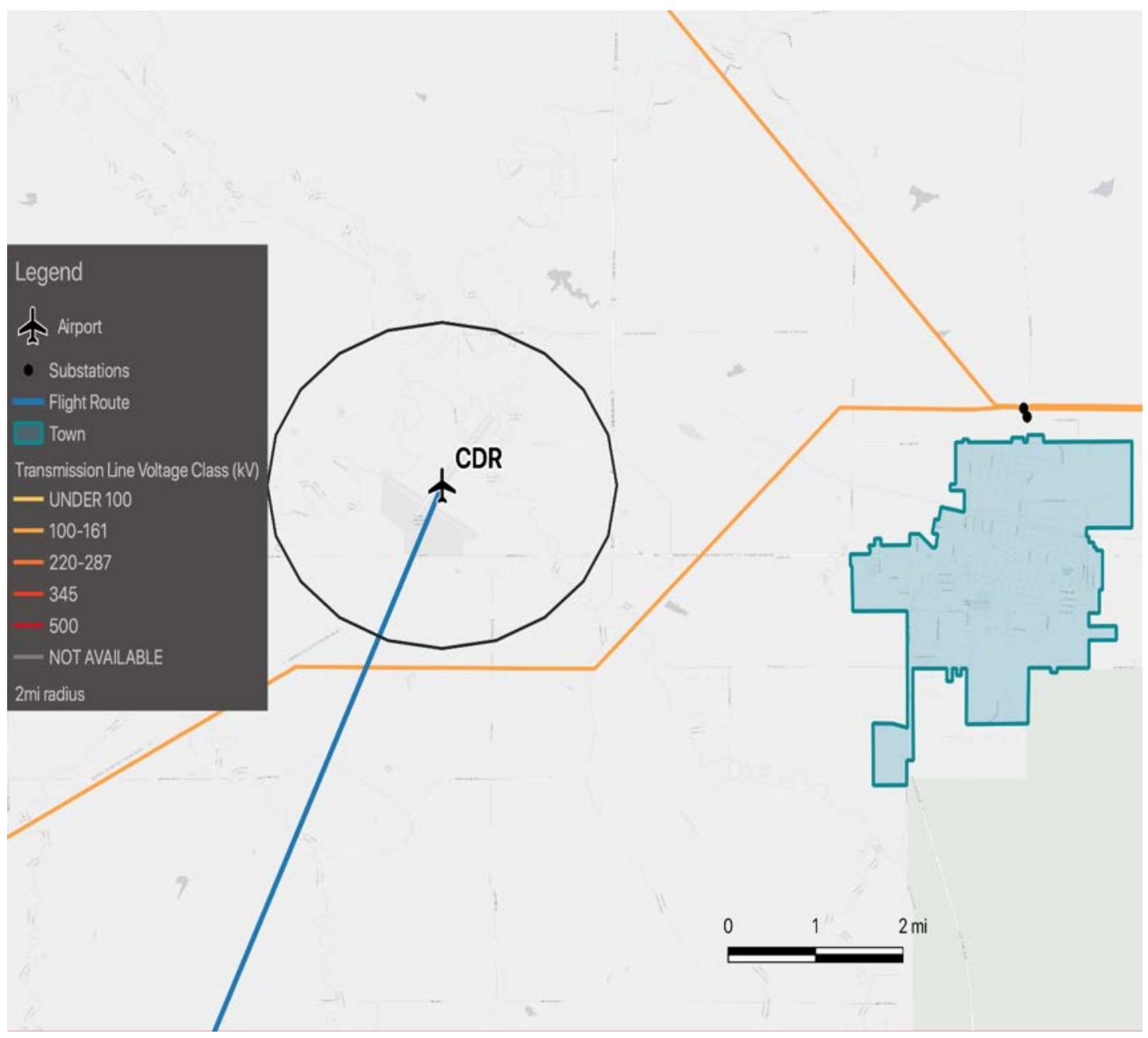

Figure 5. Transmission lines and substations near Chadron, Nebraska, airport Illustration by Emma Robertson, NREL 


\section{Conclusions and Future Research}

As the aviation industry electrifies, many challenges will need to be overcome. Stakeholders across industry, academia, and government will need to work together to address a variety of questions. Developing improved battery technologies for long-range flight, understanding the impact of electric aviation on the local electrical grid structures, and developing appropriate charging infrastructure all need to be addressed to enable widespread adoption of these new technologies.

Figure 6 displays a holistic look at the energy requirements that need to be considered in integrating electric aircraft into the airport structure. NREL, with its leading role in vehicle electrification and energy systems integration and analysis, is supporting key industry and governmental initiatives to transform this facet of the global energy system. NREL capabilities span early stage technology development through energy system design and integration. For example, NREL's large-scale Advanced Research on Integrated Energy Systems research platform provides large-scale hardware-in-the-loop testing of up to 10-MW energy systems, including energy security and resilience, battery systems, charging infrastructure, hydrogen and fuel cell technology, power electronics, control systems, and electric machines. In addition, NREL helps stakeholders analyze and plan for the technical, economic, environmental, and societal impact of energy system transformation. Figure 6 illustrates how the Advanced Research on Integrated Energy Systems' testing capabilities could address the types of integrated energy challenges future airports will face.

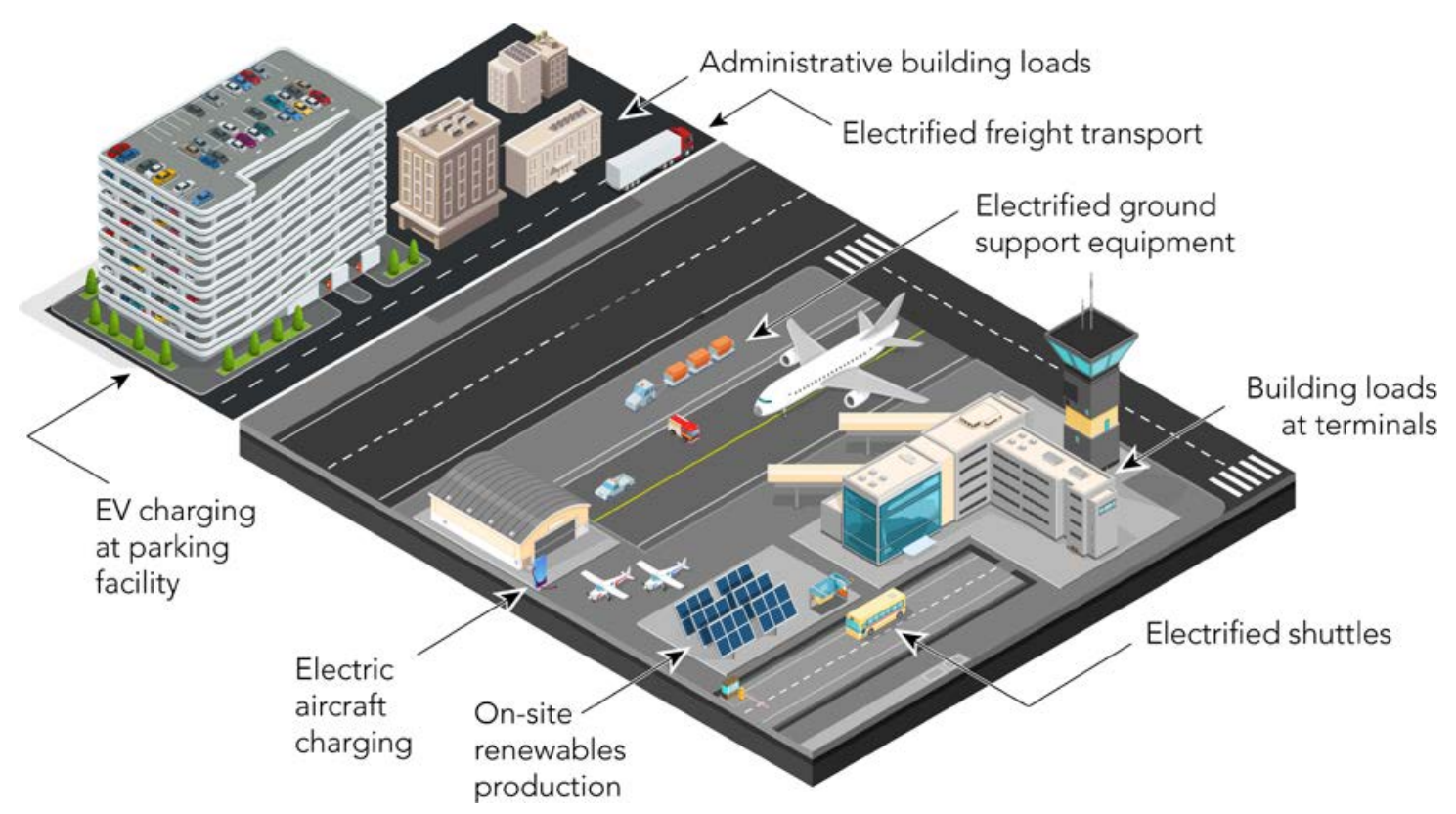

Figure 6. Integrated energy requirements of future airports

Illustration by Josh Bauer, NREL

$\mathrm{EV}=$ electric vehicle

Once the technological challenges of electric aviation are understood and addressed, this new sector will provide an avenue for significant reductions in emissions, lower costs, and increased energy security to a rapidly growing electrified aviation market. 


\section{References}

Ansys. 2020. "Connecting the World with Middle-Mile, Electric Powered Flights." Ansys. https://www.ansys.com/dimensions-magazine/fall-2019/connecting-the-world-with-flights.

Antcliff, Kevin, Nicholas Borer, Sky Sartorius, Pasha Saleh, Robert Rose, Maxime Gariel, Joseph Oldham, et al. 2021. Regional Air Mobility: Leveraging Our National Investments to Energize the American Travel Experience. NASA. April 2021. https://sacd.larc.nasa.gov/sacd/wp-content/uploads/sites/102/2021/04/2021-04-20-RAM.pdf.

Baraniuk, Chris. 2020. "The Largest Electric Plane Ever to Fly.” BBC. June 17, 2020. https://www.bbc.com/future/tags/transport.

Baumeister, Stefan, Abraham Leung, and Tim Ryley. 2020. "The Emission Reduction Potentials of First Generation Electric Aircraft (FGEA) in Finland." Journal of Transport Geography. May: 102730. https://doi.org/10.1016/j.jtrangeo.2020.102730.

Blain, Loz. 2020. "State of the Game: The Key Players in the Emerging eVTOL Air Taxi Market." New Atlas. May 23, 2020. https://newatlas.com/aircraft/evtol-air-taxi-flying-carmarket-players/

Bogaisky, Jeremy. 2019. "Boeing Backs Away from Zunum Aero, Founders Struggle To Raise Money After Laying Off Staff." Forbes. July 2, 2019. https://www.forbes.com/sites/jeremybogaisky/2019/07/02/zunum-aero-nears-zero-foundersstruggle-to-raise-money-after-laying-off-staff/.

Boyle, Alan. 2019. "Magnix Revs Up Electric Motors for Harbour Air Seaplane Flight Tests in December." GeekWire. November 15, 2019. https://www.geekwire.com/2019/magnix-revselectric-motors-harbour-air-seaplane-flight-test-december/.

Burns \& McDonnell. 2019. In Depot Charging and Planning Study: Foothill Transit. Report Project No. 110549. September 9, 2019. Kansas City, MO: Burns \& McDonnell.

http://foothilltransit.org/wp-content/uploads/2014/05/Burns-McDonnell-In-Depot-Charging-andPlanning-Study.pdf.

Davis, Stacy C., and Robert G. Boundy. 2019.Transportation Energy Data Book: Edition 37. Oak Ridge, TN: Oak Ridge National Laboratory. https://doi.org/10.2172/1493136.

- 2020. Transportation Energy Data Book: Edition 39. Oak Ridge, TN: Oak Ridge National Laboratory. https://doi.org/10.2172/1767864.

DOE (U.S. Department of Energy Office of Energy Efficiency and Renewable Energy). 2016. Bioenergy Technologies Office Multi-Year Program Plan March 2016. DOE/EE-1385. March 2016. https://www.energy.gov/sites/default/files/2016/07/f33/mypp march2016.pdf.

. n.d. "Developing Infrastructure to Charge Plug-In Electric Vehicles." https://afdc.energy.gov/fuels/electricity infrastructure.html. 
Domonoske, Camila. 2021. "From Amazon to FedEx, the Delivery Truck Is Going Electric." NPR. March 17, 2021. https://www.npr.org/2021/03/17/976152350/from-amazon-to-fedex-thedelivery-truck-is-going-electric.

Downing, Shane. 2019. "6 Electric Aviation Companies to Watch.” GreenBiz (August 20, 2019). https:/www.greenbiz.com/article/6-electric-aviation-companies-watch

EIA (U.S. Energy Information Administration). 2019. "IA Projects Energy Consumption in Air Transportation to Increase through 2050." Today in Energy (November 6, 2019). Accessed August 2020. https://www.eia.gov/todayinenergy/detail.php?id=41913.

FAA (Federal Aviation Administration). 2018. Overview of Office of Airports Engagement on Environmental (EJ) Issues. Presented by Thomas Cuddy. https://www.faa.gov/about/office_org/headquarters_offices/acr/eeo training/past_conferences/air port_civil_rights training_ninth_national_2018_conference/media/Title_VI_Overview_of_OAE on Environ Justice.pdf.

Hinman, Brian L. 2019. "Better Together: Electric Aircraft Charge Connector Standardization." Medium. July 9, 2019. https://brian-is-flyin.medium.com/better-together-electric-aircraft-chargeconnector-standardization-294efbdedf57.

Holland, Frank. 2021. "Beta Hopes Its Electric Vertical Aircraft Deal with UPS Validates this New Mode of Transport.” CNBC. April 7, 2021. https://www.cnbc.com/2021/04/07/beta-hopesevtol-aircraft-deal-with-ups-validates-new-transport-mode.html.

Howell Hanano, Elizabeth J. n.d. "Green for Take Off: Inside the Electric Airplane Industry." Toptal. https://www.toptal.com/finance/market-research-analysts/electric-airplanes.

ICAO (International Civil Aviation Organization). 2019. Destination Green: The Next Chapter: 2019 Environmental Report: Aviation and Environment. International Civil Aviation Organization (ICAO). https://www.icao.int/environmental-protection/pages/envrep2019.aspx.

EIA (U.S. Energy Information Administration). 2019. International Energy Outlook 2019 with Projections to 2050. Washington, D.C.: U.S. Energy Information Administration. https://www.eia.gov/outlooks/ieo/pdf/ieo2019.pdf.

Intelligent Aerospace. 2020. "Zunum Aero and Safran Team Up To Power Hybrid-to-Electric Commercial Aircraft.” Intelligent Aerospace. March 23, 2020. https://www.intelligentaerospace.com/commercial/article/14170301/electric-commercial-aircraft.

Langford, John S., and David K. Hall. 2020. "Electrified Aircraft Propulsion." The Bridge: Linking Engineering and Society (Summer Bridge Issue on Aeronautics) 50 (2): 21-28. https://www.nae.edu/234444/Electrified-Aircraft-Propulsion.

Mackay, Steve. 2019. “The Oncoming Battery Revolution.” Engineering Institute of Technology. February 13, 2019. https:/www.eit.edu.au/the-oncoming-battery-revolution/.

MarketsandMarkets. n.d. “Electric Aircraft Market Worth 121.8 Million USD by 2023.” Press release. MarketsandMarkets. https://www.marketsandmarkets.com/PressReleases/electricaircraft.asp. 
National Academies (National Academies of Sciences, Engineering, and Medicine). 2016. Commercial Aircraft Propulsion and Energy Systems Research: Reducing Global Carbon Emissions. Washington, D.C.: The National Academies Press. https://doi.org/10.17226/23490.

NIT (National Institute of Aerospace). n.d. Powered for Take Off: NIA-NASA Urban Air Mobility Electric Infrastructure Study: eVTOL Electrical Infrastructure Study for UAM Aircraft. Walnut Creek, CA: Black \& Veatch. https://www.bv.com/sites/default/files/201911/NASA eVTOL Electric Infrastructure Study.pdf.

Randall, Chris. 2019. "Electro.Aero Presents DC Charging for Electric Aircraft." electrive.com. October 26, 2019. https://www.electrive.com/2019/10/26/electro-aero-presents-dc-chargingsolution-for-electric-aircraft/.

Reid, David. 2019. "All-Electric Jet Firm Eviation Announces US Regional Airline as First Customer, Predicts Delivery in 2022." CNBC. June 18, 2019.

https://www.cnbc.com/2019/06/18/all-electric-jet-firm-eviation-announces-us-airline-as-firstcustomer.html.

Selkirk, Diane. 2020. "Is This the Start of an Aviation Revolution? BBC. February 11, 2020. https://www.bbc.com/future/article/20200211-the-electric-plane-leading-a-revolution.

Sigler, Dean. 2018. "Liquid Batteries for Aircraft?" Sustainable Skies. August 20, 2018. http://sustainableskies.org/liquid-batteries-aircraft/

Singh, Sumit. 2021. "Eviation Moves Closer To Flying Its All-Electric Alice Aircraft." Simple Flying. May 15, 2021. https://simpleflying.com/eviation-closer-alice/.

Thurber, Matt. 2019. "Eviation's Alice To Fly This Year.” Aviation International News. June 19, 2019. https://www.ainonline.com/aviation-news/air-transport/2019-06-19/eviations-alice-flyyear.

UBS. 2019. "Green Power: Will Climate Change Propel the Sector Towards Hybrid Electric Aviation.” UBS. June 11, 2019. https:/www.ubs.com/global/en/investment-bank/infocus/2019/electric-planes.html.

United. 2021. "United Adding Supersonic Speeds with New Agreement to Buy Aircraft from Boom Supersonic." United. June 3, 2021. https://hub.united.com/2021-06-03-united-addingsupersonic-speeds-with-new-agreement-to-buy-aircraft-from-boom-supersonic-2653216403.html

USDOT (U.S. Department of Transportation) Current and Historical Status Reports, Reports for Subsidized EAS communities, September 2020, Accessed 8/2021.

https://www.transportation.gov/office-policy/aviation-policy/essential-air-service-reports.

Walków, Marcin, and Qayyah Moynihan. 2019. "This Electric Plane Takes Just One Hour to Charge and Can Travel 160 Kilometers for Just \$5.” Business Insider (June 19, 2019). https://www.businessinsider.com/electric-plane-charges-in-hour-can-cover-160km-2019-6/. 
White, Tim. 2020. "Hybrid-Electric Propulsion: A Great Start to Reducing Aviation's Carbon Footprint." Originally published in Regional International/ERA magazine, March 2020.

https://www.collinsaerospace.com/en/newsroom/Stories/2020/03/White-Hybrid-ElectricPropulsion-Great-Start-Reducing-Aviation-Carbon-Footprint.

WSDOT (WSDOT Aviation Division). 2019. Electric Aircraft Working Group Report. June 2019. https://wsdot.wa.gov/sites/default/files/2019/07/15/ElectricAircraftWorkingGroupReportJune2019.pdf

WSDOT (WSDOT Aviation Division). 2020. Washington Electric Aircraft Feasibility Study. Prepared by WSP. November 2020. https://wsdot.wa.gov/sites/default/files/2020/11/18/ElectricAircraft-Feasibility-Study-Nov2020.pdf. 


\section{Appendix. Electric Aviation Projects as of 2019}

The electric aircraft market is currently a mix of established aircraft manufactures and startup companies, with some companies closing over time for technical or financial reasons and new companies entering the market. Table A-1 shows projects as of 2019, from a 2019 International Civil Aviation Organization publication (ICAO 2019) (used with ICAO permission). Manufacturers that have closed or projects that have ended or appear to be dormant as of July 2021 include Zunum Aero, Airbus (A^3) Vahana, Airbus/Audi Pop-up, Extra aircraft/ Siemens Extra 330LE, and Magnus Aircraft/ Siemens eFusion.

\section{Table A-1. Electric Aviation Projects as of 2019}

\begin{tabular}{|c|c|c|c|c|c|c|c|c|c|c|}
\hline Project & Tyрe & Category & $\begin{array}{l}\text { Maximum } \\
\text { Takeoff } \\
\text { Weight (kg) }\end{array}$ & Pax & $\begin{array}{l}\text { Target } \\
\text { Entry in } \\
\text { Service }\end{array}$ & $\begin{array}{l}\text { Cruise } \\
\text { Altitude } \\
\text { (FT) }\end{array}$ & $\begin{array}{l}\text { Cruise } \\
\text { Speed } \\
(\mathbf{k t})\end{array}$ & $\begin{array}{l}\text { Payload } \\
\text { (kg) }\end{array}$ & Range (KM) & $\begin{array}{l}\text { Engine } \\
\text { Power (kW) }\end{array}$ \\
\hline $\begin{array}{l}\text { Airbus/ } \\
\text { Siemens/ Rolls } \\
\text { Royce E-Fan Xa }\end{array}$ & $\begin{array}{l}\text { Hybrid- } \\
\text { electric }\end{array}$ & $\begin{array}{l}\text { Large } \\
\text { commercial } \\
\text { aircraft }\end{array}$ & N.A. & 100 & 2030 & N.A. & N.A. & 6,650 & N.A. & 2,000 \\
\hline $\begin{array}{l}\text { NASA X-57 } \\
\text { Maxwell }\end{array}$ & Electric & $\begin{array}{l}\text { General } \\
\text { aviation/ } \\
\text { recreational } \\
\text { aircraft }\end{array}$ & N.A. & 2 & 2020-2021 & 9,000 & 149.464 & N.A. & 160 & $60+10$ \\
\hline $\begin{array}{l}\text { Zunum Aero } \\
\text { ZA10 }^{15}\end{array}$ & $\begin{array}{l}\text { Hybrid- } \\
\text { Electric }\end{array}$ & Business air & $t 5,216.3$ & 12 & 2020 & $\begin{array}{l}\text { Max } \\
25,000\end{array}$ & 295 & 1,134 & 1,127 & $1,000+500$ \\
\hline Uber Elevate & Electric & VTOL & N.A. & up to 4 & 2023 & $\begin{array}{l}1,000- \\
2,000\end{array}$ & 130 & 498.96 & 97 & N.A. \\
\hline Lilium & Electric & VTOL & 639.6 & 5 & 2025 & 3,300 & 160 & 200 & 300 & 320 \\
\hline $\begin{array}{l}\text { Pipistrel Alpha } \\
\text { Electro }\end{array}$ & Electric & $\begin{array}{l}\text { General } \\
\text { aviation/ } \\
\text { recreational } \\
\text { aircraft }\end{array}$ & 549.8 & 2 & 2018 & N.A. & 85 & 200 & 600 & 60 \\
\hline
\end{tabular}




\begin{tabular}{|c|c|c|c|c|c|c|c|c|c|c|}
\hline Project & Type & Category & $\begin{array}{l}\text { Maximum } \\
\text { Takeoff } \\
\text { Weight (kg }\end{array}$ & Pax & $\begin{array}{l}\text { Target } \\
\text { Entry in } \\
\text { Service }\end{array}$ & $\begin{array}{l}\text { Cruise } \\
\text { Altitude } \\
\text { (FT) }\end{array}$ & $\begin{array}{l}\text { Cruise } \\
\text { Speed } \\
(\mathbf{k t})\end{array}$ & $\begin{array}{l}\text { Payload } \\
\text { (kg) }\end{array}$ & Range (KM) & $\begin{array}{l}\text { Engine } \\
\text { Power (kW) }\end{array}$ \\
\hline $\begin{array}{l}\text { Kitty Hawk } \\
\text { Cora }\end{array}$ & Electric & VTOL & N.A. & 2 & 2022 & $\begin{array}{l}\text { Up to } \\
3,000\end{array}$ & 95 & N.A. & 100 & N.A. \\
\hline $\begin{array}{l}\text { Kitty Hawk } \\
\text { Flyer }\end{array}$ & Electric & VTOL & N.A. & 1 & & 10 & 17 & N.A. & 10.7 & \\
\hline $\begin{array}{l}\text { Airbus }\left(A^{\wedge} 3\right) \\
\text { Vahana }\end{array}$ & Electric & VTOL & 725.7 & 1 & 2020 & N.A. & 95 & 113 & 100 & 360 \\
\hline $\begin{array}{l}\text { Airbus City } \\
\text { Airbus }\end{array}$ & Electric & VTOL & $2,199.2$ & 4 & 2023 & N.A. & 59 & N.A. & 96 & $8 * 100$ \\
\hline $\begin{array}{l}\text { Airbus/Audi } \\
\text { Pop up }\end{array}$ & Electric & VTOL & N.A. & 2 & N.A. & N.A. & N.A. & N.A. & 130 & N.A. \\
\hline $\begin{array}{l}\text { Boeing Aurora } \\
\text { eVTOL }\end{array}$ & Electric & VTOL & 798.3 & 2 & 2020 & N.A. & 48.6 & N.A. & N.A. & N.A. \\
\hline Ehang 184 & Electric & VTOL & N.A. & 1 & N.A. & 9,843 & 54 & 100 & 16 & 106 \\
\hline Volocopter 2X & Electric & VTOL & 450 & 2 & 2018 & 6,562 & 27 & 160 & 27 & N.A. \\
\hline Eviation Alice & Electric & $\begin{array}{l}\text { Business } \\
\text { aircraft }\end{array}$ & $6,349.8$ & 9 & 2021 & 32,808 & 240 & 1,250 & 1,046 & N.A. \\
\hline $\begin{array}{l}\text { Wright } \\
\text { Electric/Easy } \\
\text { Jet }\end{array}$ & Electric & $\begin{array}{l}\text { Large } \\
\text { commercial } \\
\text { aircraft }\end{array}$ & N.A. & $\begin{array}{l}\text { at least } \\
120\end{array}$ & 2027 & N.A. & N.A. & N.A. & 539 & $3 * 260$ \\
\hline $\begin{array}{l}\text { Extra aircraft/ } \\
\text { Siemens Extra } \\
\text { 330LE }\end{array}$ & Electric & $\begin{array}{l}\text { General } \\
\text { aviation/ } \\
\text { recreational } \\
\text { aircraft }\end{array}$ & $1,000.1$ & 2 & 2016 & 9,843 & \multicolumn{2}{|c|}{184 (top) N.A. } & N.A. & 260 \\
\hline $\begin{array}{l}\text { Magnus } \\
\text { Aircraft/ } \\
\text { Siemens } \\
\text { eFusion }\end{array}$ & $\begin{array}{l}\text { Hybrid di } \\
\text { electric }\end{array}$ & $\begin{array}{l}\text { - General } \\
\text { aviation/ } \\
\text { recreational } \\
\text { aircraft }\end{array}$ & 600.1 & 2 & N.A. & N.A. & $100-130$ & N.A. & 1,100 & 60 \\
\hline
\end{tabular}




\begin{tabular}{|c|c|c|c|c|c|c|c|c|c|c|}
\hline Project & Type & Category & $\begin{array}{l}\text { Maxin } \\
\text { Takec } \\
\text { Weigh }\end{array}$ & Pax & $\begin{array}{l}\text { Target } \\
\text { Entry in } \\
\text { Service }\end{array}$ & $\begin{array}{l}\text { Cruise } \\
\text { Altitude } \\
\text { (FT) }\end{array}$ & $\begin{array}{l}\text { Cruise } \\
\text { Speed } \\
(k t)\end{array}$ & $\begin{array}{l}\text { Payload } \\
\text { (kg) }\end{array}$ & Range (KM) & $\begin{array}{l}\text { Engine } \\
\text { Power (kW) }\end{array}$ \\
\hline Solar Impulse 2 & Electric & $\begin{array}{l}\text { General } \\
\text { aviation/ } \\
\text { recreational } \\
\text { aircraft }\end{array}$ & N.A. & 1 & N.A. & 27,887 & 38 & N.A. & N.A. & N.A. \\
\hline $\begin{array}{l}\text { Bye Aerospace } \\
\text { Sun Flyer } 2\end{array}$ & Electric & $\begin{array}{l}\text { General } \\
\text { aviation/ } \\
\text { recreational } \\
\text { aircraft }\end{array}$ & 861.8 & 2 & N.A. & N.A. & $55-135$ & 363 & N.A. & 90 \\
\hline $\begin{array}{l}\text { Ampaire } \\
\text { TailWind }\end{array}$ & Electric & business air & ft N.A. & 9 & N.A. & N.A. & N.A. & N.A. & 161 & N.A. \\
\hline $\begin{array}{l}\text { Embraer } \\
\text { Dreammaker }\end{array}$ & Electric & VTOL & N.A. & N.A. & 2024 & $\begin{array}{l}2,600- \\
3,300\end{array}$ & N.A. & N.A. & N.A. & N.A. \\
\hline Bell Nexus & Electric & VTOL & N.A. & 4 & N.A. & N.A. & N.A. & N.A. & N.A. & N.A. \\
\hline $\begin{array}{l}\text { Boeing Sugar } \\
\text { Volt }\end{array}$ & $\begin{array}{l}\text { Hybrid- } \\
\text { electric }\end{array}$ & $\begin{array}{l}\text { Large } \\
\text { commercial } \\
\text { aircraft }\end{array}$ & N.A. & 135 & 2030-2050 & N.A. & N.A. & N.A. & 6,482 & N.A. \\
\hline $\begin{array}{l}\text { DigiSky } \\
\text { SkySpark }\end{array}$ & Electric & $\begin{array}{l}\text { General } \\
\text { aviation/ } \\
\text { recreational } \\
\text { aircraft }\end{array}$ & N.A. & 2 & N.A. & N.A. & 162 (top) & N.A. & 500 & 65 \\
\hline Hamilton aEro & Electric & $\begin{array}{l}\text { General } \\
\text { aviation/ } \\
\text { recreational } \\
\text { aircraft }\end{array}$ & 420 & 1 & 2017 & N.A. & 92 & N.A. & 160 & 80 \\
\hline Dufour aEro 2 & Electric & VTOL & N.A. & 2 & N.A. & N.A. & 173 & N.A. & 120 & N.A. \\
\hline \multicolumn{2}{|c|}{$\begin{array}{l}\text { PC Aero Elektra Electric } \\
\text { One Solar }\end{array}$} & $\begin{array}{l}\text { General } \\
\text { aviation/ } \\
\text { recreational } \\
\text { aircraft }\end{array}$ & 300 & 1 & N.A. & 19,600 & 76 & 100 & 600 & 32 \\
\hline
\end{tabular}




\begin{tabular}{|c|c|c|c|c|c|c|c|c|c|c|}
\hline Project & Type & Category & \multicolumn{2}{|c|}{$\begin{array}{l}\text { Maximum Pax } \\
\text { Takeoff } \\
\text { Weight (kg) }\end{array}$} & \multirow{2}{*}{$\begin{array}{l}\text { Target } \\
\text { Entry in } \\
\text { Service } \\
\text { N.A. }\end{array}$} & \multirow{2}{*}{$\begin{array}{l}\begin{array}{l}\text { Cruise } \\
\text { Altitude } \\
\text { (FT) }\end{array} \\
65,616\end{array}$} & \multirow{2}{*}{$\begin{array}{l}\begin{array}{l}\text { Cruise } \\
\text { Speed } \\
(k t)\end{array} \\
37.8\end{array}$} & \multirow[t]{2}{*}{$\begin{array}{l}\text { Payload } \\
\text { (kg) }\end{array}$} & \multirow[t]{2}{*}{ Range (KM) } & \multirow[t]{2}{*}{$\begin{array}{l}\text { Engine } \\
\text { Power (kW) }\end{array}$} \\
\hline $\begin{array}{l}\text { PC Aero Elek } \\
\text { Two Solar }\end{array}$ & a Electric & $\begin{array}{l}\text { General } \\
\text { aviation/ } \\
\text { recreational } \\
\text { aircraft }\end{array}$ & 450 & 2 & & & & & & \\
\hline $\begin{array}{l}\text { PC Aero Elek } \\
\text { Solar Trainer }\end{array}$ & a Electric & $\begin{array}{l}\text { General } \\
\text { aviation/ } \\
\text { recreational } \\
\text { aircraft }\end{array}$ & 600 & 2 & N.A. & & 76.6 & 260 & 400 & 32 \\
\hline $\begin{array}{l}\text { Volta Volare } \\
\text { DaVinci }\end{array}$ & $\begin{array}{l}\text { Hybrid- } \\
\text { electric }\end{array}$ & $\begin{array}{l}\text { General } \\
\text { aviation/ } \\
\text { recreational } \\
\text { aircraft }\end{array}$ & N.A. & $2+2$ & 2017 & 24000 & 160 & N.A. & N.A. & N.A. \\
\hline $\begin{array}{l}\text { Yuneec } \\
\text { International } \\
\text { E430 }\end{array}$ & Electric & $\begin{array}{l}\text { General } \\
\text { aviation/ } \\
\text { recreational } \\
\text { aircraft }\end{array}$ & 430 & 2 & N.A. & 9,840 & 52 & N.A. & N.A. & N.A. \\
\hline
\end{tabular}

